\title{
Effects of supplements differing in fatty acid profile to late gestational beef cows on cow performance, calf growth performance, and mRNA expression of genes associated with myogenesis and adipogenesis
}

\section{Taoqi Shao}

University of Illinois at Urbana-Champaign

Frank A. Ireland

University of Illinois at Urbana-Champaign

Joshua C. McCann

University of Illinois at Urbana-Champaign

Daniel W. Shike ( $\nabla$ dshike@illinois.edu )

University of Illinois at Urbana-Champaign

Research

Keywords: Beef cattle, Carcass characteristics, Fatty acids, Fetal programming, Late gestation, mRNA expression

Posted Date: February 12th, 2021

DOI: https://doi.org/10.21203/rs.3.rs-127948/v2

License: (c) (1) This work is licensed under a Creative Commons Attribution 4.0 International License. Read Full License 


\section{Abstract}

Background: Maternal nutrition during gestation affects fetal development, which has long-term programming effects on offspring postnatal growth performance. With a critical role in protein and lipid metabolism, essential fatty acids can influence the development of muscle and adipose tissue. The experiment investigated the effects of late gestation supplements ( $77 \mathrm{~d}$ prepartum), either rich in saturated and monounsaturated fatty acids (CON; $155 \mathrm{~g} / \mathrm{cow} / \mathrm{d}$ EnerGII) or polyunsaturated fatty acids (PUFA; $80 \mathrm{~g} / \mathrm{cow} / \mathrm{d}$ Strata and $80 \mathrm{~g} / \mathrm{cow} / \mathrm{d}$ Prequel), on cow performance and subsequent calf growth performance as well as mRNA expression in longissimus muscle (LM) and subcutaneous adipose tissue at birth and weaning.

Results: There was no difference $(P \geq 0.34)$ in cow body weight (BW) or body condition score from presupplementation through weaning. Relative concentrations of C18:3n-3 and C20:4n-6 decreased $(P \leq$ 0.05 ) to a greater extent from mid-supplementation to calving for PUFA compared to CON cows. Cow plasma C20:0, C20:5n-3, and C22:6n-3 were increased ( $P \leq 0.01)$ in PUFA during supplementation period. At birth, PUFA steers had greater $(P=0.01)$ plasma $\mathrm{C} 20: 5 n-3$. No differences $(P \geq 0.33)$ were detected in steer birth BW or dam milk production, however, CON steers tended $(P=0.06)$ to have greater pre-weaning average daily gain and had greater $(P=0.05)$ weaning BW compared to PUFA. For mRNA expression in steers: $M Y H 7$ and $C / E B P \beta$ in $L M$ increased $(P \leq 0.04)$ to a greater extent from birth to weaning for PUFA compared to CON; MYF5 in LM and $C / E B P \beta$ in adipose tissue tended $(P \leq 0.08)$ to decrease more from birth to weaning for CON compared to PUFA; $S C D$ in PUFA adipose tissue tended $(P=0.08)$ to decrease to a greater extent from birth to weaning than CON. In addition, maternal PUFA supplementation tended $(P=$ 0.08 ) to decrease MYOG mRNA expression in LM and decreased $(P=0.02)$ ZFP423 in adipose tissue during the pre-weaning stage.

Conclusions: Late gestation PUFA supplementation decreased pre-weaning growth performance of the subsequent steer progeny compared to CON supplementation, which could have been a result of downregulated mRNA expression of myogenic genes during pre-weaning period.

\section{Background}

Fetal programming is the response to a specific challenge to the organism during a critical developmental period that leads to persistent effects [1]. In the last few years, fetal programming research has been focusing on specific nutrients, like fatty acids [2-5] and one-carbon metabolites [6-8]. By supplementing dietary fatty acids, the fatty acid profile of blood and tissues of the dams can be altered [9]. Meanwhile, maternal circulating fatty acids can be transferred to the fetus through placenta and alter the fatty acid profile of the fetus [10]. Therefore, supplementing different fatty acids to dams can modify the fatty acids transferred to the fetus. Fatty acids, especially essential fatty acids (EFAs), are important ligands for regulating protein and lipid metabolism, which can influence the development of fetal muscle and adipose tissue during critical periods. 
Recent studies [2,5] conducted under spring-calving and hay-based systems reported supplementation of Ca salts of polyunsaturated fatty acids during the last $90 \mathrm{~d}$ of gestation improved offspring growth performance during finishing phases and carcass characteristics. A series of sheep studies indicated that lamb performance was not only affected by lamb diet, but also influenced by maternal fatty acid supplementation during late gestation $[4,11]$. It was also reported that late gestation supplementation of $\mathrm{n}-3$ fatty acids to ewes increased mRNA expression of regulator of lipid mediator formation in fetal liver [12]. In cell studies, the function of Peroxisome proliferator-activated receptor gamma (PPARY), which is the key gene for adipogenic differentiation [13], is known to be stimulated by $n-6$ fatty acids such as C18:2 [14,15]. However, n-3 fatty acids, especially C20:5n-3 (EPA) and C22:6n-3 (DHA), activate PPARa, which leads to increased transcription of lipolytic genes and decreased transcription of lipogenic genes [16]. It was also reported that dietary n-3 fatty acids intervention is critical for the development and function of bovine LM [17]. Human studies revealed that changes of maternal PUFA status during late gestation altered childhood body composition in young ages [18-20]. However, little is known about the mechanism of different responses in ruminants, especially beef cattle under fall-calving grazing systems. Therefore, the objective of the current study was to investigate the effects of supplementation differing in fatty acid profile to late gestation beef cows on cow performance, subsequent steer progeny growth performance during pre-weaning period, and mRNA expression in longissimus muscle and subcutaneous adipose tissue. We hypothesized that cows would have similar performance since supplements were isocaloric and isonitrogenous and terminated at calving, while steers from dams supplemented with PUFA would have greater growth performance due to upregulated myogenesis and adipogenesis by fetal programming of EFAs.

\section{Materials And Methods}

Experimental animals were managed according to the guidelines recommended in the Guide for the Care and Use of Agricultural Animal in Agricultural Research and Teaching (Federation of Animal Science Societies, 2010). All experimental procedures were approved by the Institutional Animal Care and Use Committee of the University of Illinois (IACUC \# 18109).

\section{Experiment design, animals, and diets}

Ninety-six, fall-calving beef cows (body weight [BW] = $601 \pm 76 \mathrm{~kg}$ ) from Dixon Springs Agricultural Center, Simpson, IL were utilized for this experiment. Prior to supplementation (d -77), cows were stratified by BW, body condition score (BCS), age, and fetal sex (64 male and 32 undetermined), and allotted into 8 predominately endophyte-infected tall fescue pastures with 12 cows/pasture ( $n=4$ pastures/treatment) and pasture groups were randomly assigned to 1 of 2 treatments. Each group of cows were rotated between two pastures every 2 wk, with average stocking density of 3.0 cows per hectare. Forage availability was measured with rising plate meter at each rotation [21]. Each cow was supplemented 0.77 $\mathrm{kg}$ dry matter (DM)/d soybean hulls mixed with either $80 \mathrm{~g} \mathrm{DM} / \mathrm{d}$ Strata $+80 \mathrm{~g} \mathrm{DM} / \mathrm{d}$ Prequel (PUFA, rich in linoleic acid, eicosapentaenoic acid, and docosahexaenoic acid) or $155 \mathrm{~g} \mathrm{DM} / \mathrm{d}$ EnerGII (CON, rich in palmitic and oleic acids) for $77 \pm 6 \mathrm{~d}$ prepartum (Table 1). Calcium salts of fatty acids (Strata, Prequel, 
and EnerGII) were provided by Virtus Nutrition LLC, Corcoran, CA. The two diets were designed to be isocaloric and isonitrogenous. Nutritional and fatty acid profiles of ingredients fed to cows during late gestation are presented in Table 2. Cows were supplemented 3 times a week (Monday, Wednesday, and Friday) in 3 portable metal bunks ( $3.66 \times 0.76 \mathrm{~m}$, accessible from both sides) per group during supplementation period. Supplements were typically ingested by cows within 15 minutes. Cows were also weighed and assigned BCS at the middle of supplementation ( $d-42)$, the end of the gestation $(d-18)$, within one week post-calving ( $5 \pm 2.4 \mathrm{~d}$ post-calving), at artificial insemination (Al)-pregnancy determination ( $d$ 113), and overall-pregnancy determination ( $d 186$, same day as weaning) to monitor animal performance. Once weekly, cows that had calved and their calves were removed from the treatment groups, comingled to a common pasture, and managed as a single contemporary group from that point forward. Cows were supplemented with $2.27 \mathrm{~kg} / \mathrm{d} / \mathrm{cow}$ of dried distillers grains with solubles (DDGS; DM $81.2 \%$, crude protein [CP] 30.4\%, crude fat $10.6 \%$, neutral detergent fiber [NDF] $32.9 \%$, acid detergent fiber [ADF] 11.3\%) and soybean hulls (DM 81.7\%, CP 10.2\%, crude fat $0.8 \%$, NDF $61.7 \%$, ADF $43.8 \%$ ) in ratio of $50: 50$ during post-calving grazing period. Cows were provided with ad libitum hay (DM $76.0 \%$, CP 9.4\%, NDF $62.9 \%$, and ADF 35.7\%) from d 39 to weaning as forage availability declined in the fall. Cows were synchronized using the 7-day Co-Synch + controlled internal drug-release (Pfizer Animal Health, New York, NY) procedure [22] and artificially inseminated (Al; $78 \pm 6 \mathrm{~d}$ post-calving). Ten days after Al, cows were exposed to 2 clean-up bulls for a $79 \mathrm{~d}$ breeding season. Pregnancy diagnosis to $\mathrm{Al}$ and overall pregnancy were performed $35 \mathrm{~d}$ and $98 \mathrm{~d}$ after Al. Pregnancy diagnosis was conducted by a trained technician with ultrasonography (Aloka 500 instrument, Wallingford, CT).

Cows were vaccinated at the initiation of the supplementation ( $d-77)$ and the end of gestation $(d-18)$. On d -77, cows were administered with $2 \mathrm{~mL}$ Leptoferm- 5 (Zoetis, Florham Park, NJ), $1 \mathrm{~mL}$ Anaplasmosis vaccine (University Products L.L.C., Baton Rouge, LA), and $2 \mathrm{~mL}$ Auto. M. Bovis. (Pinkeye vaccine customized by Newport Laboratories, Worthington, MN). In addition, 2 Patriot Insecticide Cattle Ear Tags (Bayer, Shawnee Mission, KS) and Ivermectin (Norbrook, UK) were applied to the cows. On d -18, $5 \mathrm{~mL}$ Bovishield Gold FP5 VL5 HB (Zoetis), 5 mL Covexin 8 (Merck Animal Health), 7mL MU-SE (Zoetis), and 2 $\mathrm{mL}$ ScourGuard 4KC (Zoetis) and Cylence (Bayer) were administered.

There were 12 cows from PUFA groups that were removed from the trial from late-supplementation to rebreed. One cow was removed at late-supplementation ( $d-18)$ because of abortion. One cow was removed because of extremely poor BCS at calving. One was removed because of having twins. Five cows were detected open at calving. Three cows were removed because of loss of calves prior to when weigh-suckle-weigh was conducted. One cow from PUFA group died on December 2018. There was one cow from CON group was removed because of a stillborn birth. There were 5 and 8 heifer calves born from CON and PUFA cows, respectfully. Data from dams of heifer calves was included for analysis of cow performance data, while heifer calves were not included for analysis of calf birth BW, weaning BW, or mRNA expression.

Within $24 \mathrm{~h}$ after calving, calf birth BW was recorded and bull calves were castrated. Calves were provided with 1 mL BO-SE (Merck Animal Health), 20 mL Bovi-Sera (Colorado Serum Company, Denver, CO), and 1 
$\mathrm{mL}$ Vitamin A/D (VetONE, Biose, ID) at birth. Calves were vaccinated on $\mathrm{d} 60$ and $\mathrm{d} 172$ with following: 2 $\mathrm{mL}$ Auto. M. Bovis. (Newport Laboratories), $5 \mathrm{~mL}$ Covexin 8 (Merck Animal Health), $5 \mathrm{~mL}$ Bovishield Gold FP5 VL5 HB (Zoetis), 2 mL Pulmo-Guard PHM-1 (AgriLabs, St. Joseph, M0), and 1/100 dose of Synanthic (Boehringer Ingelheim Vetmedica, Duluth, GA). Two $\mathrm{mL}$ Myco-B One Dose (American Animal Health, Fort Worth, TX) and $2 \mathrm{~mL}$ Inforce 3 (Zoetis) were also administered on $\mathrm{d} 60$. Calves were weighed and weaned at $186 \pm 6 \mathrm{~d}$ of age. Pre-weaning growth was evaluated based on weaning BW and pre-weaning ADG.

\section{Sampling and analytical procedures}

Blood samples were collected from cows at pre- ( $d$-77) and mid-supplementation ( $d-42)$, and from cow/steer pairs within one week after calving (5 $2.4 \mathrm{~d}$ post-calving). Blood samples (10 mL) were collected from the jugular vein of cows and calves by using polypropylene tubes (BD Vacutainer) containing sodium heparin for plasma, and placed on ice. After centrifugation for $20 \mathrm{~min}$ at 2,000 $\mathrm{g}$ and 4 , plasma was stored at -80 until later analysis. For steer calves and their dams, individual plasma samples were thawed in 0-4 water bath [23]. A glass rod was used to stir the water in the tub for accelerating the thawing process. Thawed plasma samples that were from the same grazing group were individually added into a pooled centrifuge tube for each sampling time point. Within a pooled sample, each individual plasma sample accounted for the same percentage of the total $1.5 \mathrm{~mL}$ pooled unit.

Relative concentrations of fatty acids in pooled plasma samples were analyzed by Metabolomics Center at the Roy J. Carver Biotechnology Center (Urbana, IL, USA). Extraction was conducted twice on $100 \mu \mathrm{L}$ of sample with $300 \mu \mathrm{L}$ of methanol:chloroform (1:2) solution. Organic phase was collected, evaporated and hydrolyzed with $500 \mu \mathrm{L}$ of $3 \mathrm{~N}$ methanolic HCL contained $2 \mathrm{~g} / \mathrm{L}$ of butylated hydroxytoluene for $1 \mathrm{~h}$ at 85 ${ }^{\circ} \mathrm{C}$. Samples then were cooled to room temperature and extracted twice with $500 \mu \mathrm{L}$ of hexane. Organic phase was collected, evaporated under nitrogen and re-suspended in $100 \mu$ l. Samples were analyzed using a gas chromatography-mass spectrometry system (Agilent Inc., Palo Alto, CA, USA) consisting of an Agilent 7890B gas chromatograph and an Agilent 5977A MSD. Separation was performed on a HP$5 \mathrm{MS}(60 \mathrm{~m} \times 0.25 \mathrm{~mm}$ I.D. and $320 \mu \mathrm{m}$ film thickness) capillary column (Agilent J\&W, Palo Alto, CA, USA). The inlet temperature was $220^{\circ} \mathrm{C}, \mathrm{MSD}$ interface temperature was $230^{\circ} \mathrm{C}$ and the ion source temperature was adjusted to $230{ }^{\circ} \mathrm{C}$. An aliquot of $1 \mu \mathrm{L}$ injected in a splitless mode $(20 \mathrm{~mL} / \mathrm{min}$ for $0.75 \mathrm{~min})$. The helium carrier gas was kept at a constant flow rate of $2 \mathrm{~mL} / \mathrm{min}$. The temperature program was: $2 \mathrm{~min}$ at $150{ }^{\circ} \mathrm{C}$, followed by temperature increase of $5{ }^{\circ} \mathrm{C}$ per min to $300{ }^{\circ} \mathrm{C}$ for $3 \mathrm{~min}$. The mass spectrometer operated in positive electron impact mode at $69.9 \mathrm{eV}$ ionization energy at $\mathrm{m} / \mathrm{z} 50-600$ scan range. Target peaks were evaluated using AMDIS v2.71 and Mass Hunter Qualitative Analysis B.08.00 (Agilent Inc., Palo Alto, CA, USA) software.

Milk production was determined before breeding (64 $\pm 9 \mathrm{~d}$ postpartum) on a subset of $59 \mathrm{cow} /$ steer calf pairs (7-9 pairs per grazing group) via weigh-suckle-weigh (WSW) as described by Beal et al. [24]. Day postpartum, cow BW at calving and cow age were stratified across subset groups. Milk samples were hand stripped on a subset of cows (4 cows/pasture group; $n=32$ ) during WSW for milk composition and fatty acid profile analysis. Milk samples for composition analysis were shipped in a cooler with ice packs 
underneath the samples. Milk composition was analyzed by Dairy Lab Service Inc. (Dubuque, IA). For the milk samples that were collected for fatty acid profile analysis, the top fat layer was collected after centrifugation at $20,000 \times \mathrm{g}$ for $30 \mathrm{~min}$ at $4{ }^{\circ} \mathrm{C}$ [3] and stored at $-80{ }^{\circ} \mathrm{C}$ until shipping out to Cumberland Valley Analytical Service Inc. (CVAS; Waynesboro, PA, USA). The analysis was conducted as previously described $[25,26]$ with minor modifications. Briefly, approximately $1.6 \mathrm{mg}$ of sample was weighed and extracted using a mixture of isopropanol and hexane (2:3, vol/vol). Extracts were collected and evaporated under nitrogen at $45^{\circ} \mathrm{C}$ for about 8 min to dryness. Hexane and methyl acetate were used to dissolve lipid extracts, then fatty acid methyl esters (FAME) was synthesized by using methanolic sodium methoxide. The mixture was neutralized by oxalic acid, centrifuged and dried with calcium chloride. The FAME were separated and quantitated using PerkinElmer Clarus 590 (PerkinElmer, Shelton, CT) equipped with a fused-silica capillary column (SP-2560, $100 \mathrm{~m} 0.25 \mathrm{~mm}$ i.d. with 0.2- $\mu \mathrm{m}$ film thickness; Supelco Inc., Bellefonte, PA) and a flame ionizationdetector (FID). Hydrogen was used as the carrier gas.

Feed samples including pasture and supplement samples were collected every 2 weeks during supplementation period for proximate and fatty acid profile analysis. Forage samples were hand-clipped at the beginning of each rotation. Samples of supplement during the comingled grazing period were collected every 2 weeks for proximate analysis. All feed samples were stored at $-20{ }^{\circ} \mathrm{C}$ until further processing. The pasture forage samples were composited on a monthly basis, while supplement samples were composited for the supplementation period. The samples that were for fatty acid profile analysis were freeze dried and ground through $1 \mathrm{~mm}$ screen using a Wiley mill (Arthur, H. Thomas, Philadelphia, PA). The rest of the samples that were for proximate analysis were composited and oven dried under 55 ${ }^{\circ} \mathrm{C}$ for at least 3 days, then ground through $1 \mathrm{~mm}$ screen using a Wiley mill. Ground samples were analyzed for DM (105 ${ }^{\circ} \mathrm{C}$ oven), crude protein (Leco TruMac, LECO Corporation, St. Joseph, MI), crude fat by using Ankom XT10 Fat Extractor (Ankom Technology, Macedon, NY), NDF and ADF by using an Ankom 200 Fiber Analyzer (Ankom Technology, Macedon, NY).

Fatty acid profile analysis of the feed samples was conducted by CVAS using method of Sukhija and Palmquist [27], which was modified as follows. One $\mathrm{mL}$ of internal standard (C13:0) was added to approximately $0.5 \mathrm{~g}$ of sample, followed by adding $3.0 \mathrm{~mL}$ of $5 \%$ methanolic HCL to sample. After vortex, sample was incubated in $70{ }^{\circ} \mathrm{C}$ water bath for $2 \mathrm{~h}$. Sample was removed from water bath and cooled for $15 \mathrm{~min}$. After cooling, $5.0 \mathrm{~mL}$ of $6 \%$ Potassium Carbonate and $1 \mathrm{~mL}$ of hexane were added to the sample. Sample was centrifuged at $752 \times \mathrm{g}$ at room temperature for $10 \mathrm{~min}$. The organic layer was transferred to gas chromatography autosampler vial. Fatty acid profile was analyzed on PerkinElmer Clarus 580, split/splitless capillary injector, and FID detector with helium as the carrier gas. The fused silica capillary column was Restek Rtx-2330, $30 \mathrm{~m} \times 0.32 \mathrm{~mm}$ i.d. $\times 0.20 \mu \mathrm{m}$.

Muscle and adipose tissue biopsy samples for mRNA expression were collected from every steer calf at birth ( $5 \pm 2 \mathrm{~d}$ of age) and from a subset of steers ( $n=24,3$ from each grazing group) at 3 wk prior to weaning (165 $\pm 4 \mathrm{~d}$ of age). The 24 steers were selected based on their BW at $64 \pm 9 \mathrm{~d}$ of age being representative to the group average. For muscle biopsies, an area over the longissimus dorsi muscle from the first lumbar vertebra region on the left side of the animal was clipped closely and scrubbed 3 times 
thoroughly with betadine surgical scrub, and rinsed with $70 \%$ alcohol. Lidocaine was administered subcutaneously and intramuscularly $(5-10 \mathrm{~mL})$ over the biopsy site. After 10 min of lidocaine administration, a biopsy core of muscle (100-200 mg) was removed by using a biopsy needle (Bard MAGNUM; 12 gauge $\times 16 \mathrm{~cm}$ ). The initial Longissimus muscle biopsy was taken $5 \mathrm{~cm}$ cranial to the hook bone half way between the axis and transverse processes of the lumbar vertebrae. After completing the biopsy, pressure was applied with sterile gauze to stop any external bleeding, the surrounding area was cleansed with sterile saline to remove blood, the incision was closed with a synthetic absorbable tissue adhesive Vetbond (3M Animal Care Products, St. Paul, MN, USA), and a topical antibiotic ointment was applied. Each subsequent biopsy was taken $5 \mathrm{~cm}$ cranial to the previous biopsy site. For subcutaneous adipose tissue biopsies, an area of approximately $15 \times 15 \mathrm{~cm}$ over one side of the tail-head area was cleaned the same as muscle biopsy procedure. Lidocaine was administered similarly as muscle biopsy. Thereafter, a 3 to $4-\mathrm{cm}$ incision was made with a sterile surgical blade and the skin was pulled back using forceps, exposing the subcutaneous adipose tissue. Samples of adipose (1 to 3 grams) were taken using forceps and a single-use sterile scalpel blade. The closure of the incision was conducted similarly as in muscle biopsy. Each subsequent biopsy was collected from the opposite side of the tail-head region. Biopsy samples were immediately frozen in liquid nitrogen and stored at $-80^{\circ} \mathrm{C}$ for later mRNA expression analysis.

\section{mRNA expression}

Biopsy tissue was weighed (50 mg for muscle tissue, $200 \mathrm{mg}$ for adipose tissue) and RNA extracted using Qiazol Lysis Reagent (Qiagen Inc., Valencia, CA, USA) following the manufacturer's instruction. Genomic DNA was removed by using RNeasy Mini Kit (Qiagen Inc., Valencia, CA, USA). Concentration of RNA was measured with NanoDrop ND-1000 spectrophotometer (NanoDrop Technologies, Wilmington, DE). Quality of RNA was assessed using a 2100 Bioanalyzer (Agilent Technologies Inc., Santa Clara, CA) to calculate a RNA integrity value (RIN) for each sample. Values for RIN range from 1 to 10 (low to high quality) based on the area of $18 \mathrm{~S}$ and $28 \mathrm{~S}$ rRNA area and the height of the 28S rRNA peak. Extracted RNA had mean RIN values of $8.8 \pm 0.48$ for muscle tissue and $7.4 \pm 1.61$ for adipose. A portion of RNA was diluted to $100 \mathrm{mg} / \mathrm{L}$ using DNase/RNase free water prior to reverse transcription.

Complementary DNA (cDNA) was synthesized using 600 ng RNA, $54 \mu \mathrm{L}$ DNase/RNase free water and 6 $\mu \mathrm{L}$ Random Primers (11034731001, Roche). The mixture was incubated at $65^{\circ} \mathrm{C}$ for $5 \mathrm{~min}$ and placed on ice for 3 min. Fifty-four $\mu \mathrm{L}$ of master mix contained $24 \mu \mathrm{L} 5 \mathrm{X}$ First-Strand Buffer, $6 \mu \mathrm{L}$ Oligo dT18, $12 \mu \mathrm{L}$ 10mM dNTP mix (18427088, Thermo Fisher Scientific), $1.5 \mu \mathrm{L}$ RevertAid Reverse Transcriptase (200 U/ $\mu \mathrm{L}, \mathrm{EP0442}$, Thermo Fisher Scientific), and $0.75 \mu \mathrm{L}$ RiboLock RNase Inhibitor (40 U/ $\mu \mathrm{L}$, E00381, Thermo Fisher Scientific). The reaction was carried out in a SureCycler 8800 Thermal Cycler (Agilent Technologies Inc., Santa Clara, CA, USA) using the following temperature program: $25^{\circ} \mathrm{C}$ for $5 \mathrm{~min}, 42^{\circ} \mathrm{C}$ for $60 \mathrm{~min}$ and $70^{\circ} \mathrm{C}$ for 5 min. Resulting cDNA was then diluted 1:4 with DNase/RNase free water.

The primers used for Quantitative PCR (qPCR) are listed in Supplemental Table 1. The design and evaluation of the primers that had no references were conducted according to the method reported by 
Bionaz and Loor [28]. Sequence results for the DNA products of the designed primers are presented in Supplemental Table 2. The sequencing product was confirmed by BLASTN at the National Center for Biotechnology Information database (NCBI).

Quantitative PCR was performed using $4 \mu \mathrm{L}$ diluted cDNA combined with $6 \mu \mathrm{L}$ of a mixture composed of $5 \mu \mathrm{L}$ of Sybr Green Fast Mix ROX (QuantaBio Inc., Gaithersburg, MD, USA), $0.4 \mu \mathrm{L}$ of forward primer, 0.4 $\mu \mathrm{L}$ of reverse primer, and $0.2 \mu \mathrm{L}$ of DNase/RNase free water. All cDNA samples were analyzed in triplicate and 7-point relative standard curve plus the negative control (DNase/RNase free water instead of cDNA template) were used. The amplification protocol was as follow: $2 \mathrm{~min}$ at $50^{\circ} \mathrm{C}, 5 \mathrm{~min}$ at $95^{\circ} \mathrm{C}, 40 \mathrm{cycles}$ at $95^{\circ} \mathrm{C}$ for $5 \mathrm{~s}, 60^{\circ} \mathrm{C}$ for $30 \mathrm{~s}$. After amplification, a melting curve analysis was performed over a range of $60-95^{\circ} \mathrm{C}$ to verify that a single PCR product was generated at the end of essay. The data were calculated with the QuantStudio Real-Time PCR Software (version 1.3, Thermo Fisher Scientific). The final data were normalized using the geometric mean of internal control genes: GAPDH, ACTB, and RPLPO for muscle samples, $A C T B, B R P S 2$, and SLC35BC for adipose tissue samples. Treatment effect was analyzed for the abundance of the internal control genes; there were no treatment effects on abundance of any of the five internal control genes. Information about qPCR performance of the genes are presented in Supplemental Table 3 and 4.

\section{Statistical analysis}

Cow grazing group was considered the experimental unit for all response variables. Data, except Al pregnancy rates, were analyzed using the MIXED procedure of SAS (version 9.4; SAS Institute Inc., Cary, $N C$, USA). Outliers were checked by using Proc Reg procedure of SAS removing data with a studentized $t$ 3.0 prior to analysis. A random statement of cow group nested within treatment was included in all of the analysis under MIXED procedure when individual animal observational data was used. Treatment means were separated by the least square means function of SAS. The model for cow BW and BCS included treatment as fixed effect and cow age as covariate. The model for milk yield included the fixed effect of treatment, random effect cow group nested within treatment, and included cow age, cow milk expected progeny differences (EPD) and days postpartum as covariates. The model for calf plasma fatty acid relative concentrations, cow milk composition and milk fatty acid profile included treatment as a fixed effect and day-postpartum as a covariate. The model for steer weaning BW and pre-weaning ADG included the fixed effects of treatment and the covariate of weaning BW EPD Data concerning relative mRNA abundance but not normally distributed were transformed with a logarithmic function (LOG) or a Box-Cox family of power transformation to improve normality. For the analysis of relative mRNA abundance, treatment, time (either at-birth or at-weaning), and the interaction between treatment and time were used as fixed effects, group nested within treatment and sire were included as random effects. Repeated measure analysis of SAS was used for the analysis of cow plasma fatty acid relative concentrations. The model includes treatment, time (mid-supplementation or at-calving), and the interaction between treatment and time as fixed effects, and the concentration of the corresponding fatty acid at pre-supplementation as a covariate. The repeated measure was also used for the analysis of forage availability, and the model included treatment, time, and the interaction between treatment and 
time as fixed effects. Heterogeneous compound symmetry was used as the covariance structure for cow plasma fatty acid relative concentration and forage availability based on Akaike information criterion. The GLIMMIX procedure of SAS was used for the analysis of Al pregnancy rates, with treatment as fixed effect and age as a covariate in the model. A random statement including cow group nested within treatment, sire, and Al technician were included for the analysis of Al pregnancy rates. Overall pregnancy rate was initially analyzed with the same model as Al pregnancy rate; however, the data did not converge as some of the groups had $100 \%$ pregnancy rate. Thus, the MIXED procedure of SAS was used for the analysis of overall pregnancy rate, with each group being the observational unit. Significance was declared at $P$ 0.05, and tendencies were declared from $0.05 P 0.10$.

\section{Results}

In the current study, cows rotationally grazed on tall fescue pastures with no difference in forage availability (CON: $2015 \mathrm{~kg} \mathrm{DM} / \mathrm{ha}$, PUFA: $1957 \mathrm{~kg} \mathrm{DM} /$ ha at the end of rotation; $P=0.28$ ) during the supplementation period.

\section{Relative concentrations of selected plasma fatty acids}

There were treatment $\times$ time interactions $(P \leq 0.05$; Table 3$)$ for cow plasma concentrations of a-linolenic acid (C18:3n-3; ALA) and C20:4n-6, where the concentrations of ALA and C20:4n-6 decreased to a greater extent from mid-gestation to calving for PUFA compared to CON. The concentration of C20:3n- 6 tended $(P=0.07)$ to decrease to a greater extent from mid-gestation to calving for CON cows compared to PUFA cows. Dams supplemented with PUFA had greater $(P \leq 0.01)$ concentrations of C20:0, EPA, and DHA, but tended $(P=0.09)$ to have lower concentration of $\mathrm{C} 18: 1 \mathrm{c} 9$ compared to $\mathrm{CON}$ dams. Steers from CON dams had greater $(P \leq 0.01$; Table 4$)$ concentrations of $C 16: 1 \mathrm{c} 9, \mathrm{C} 18: 1 \mathrm{c} 9$, ALA, and C20:3n-6, while lower $(P=0.01)$ concentration of EPA compared to steers from PUFA dams. Steers from PUFA dams tended ( $P$ $=0.09)$ to have greater concentration of DHA at birth.

\section{Cow performance}

Cow BW and BCS were not affected ( $P \geq 0.34$; Table 5$)$ by late gestation supplementation at any of the time points from the start of the supplementation through weaning. The length of supplementation was not different (CON 80.3d, PUFA 81.7d; $P \geq 0.51$ ). Gestation length of the cows was not affected by late gestation supplementation ( $P=0.46$; Table 8 ). The pregnancy rates for $\mathrm{Al}$ and overall breeding season of the cows were not different $(P \geq 0.35$; Table 6$)$.

\section{Milk production, composition, and fatty acid profile}

Milk production of the cows was not different $(P=0.33$; Table 6$)$ between treatments. The milk fat, protein, lactose, total solids, or milk urea nitrogen (MUN) was not affected $(P \geq 0.23)$ by supplements during late gestation. Fatty acid profile of milk fat is shown in Table 7. The concentration of DHA was 
greater $(P=0.02)$ in milk fat of the dams supplemented with PUFA. Concentrations of other fatty acids in milk fat were not different $(P \geq 0.15)$.

\section{Pre-weaning growth performance}

Growth performance of the steer progeny during pre-weaning stage is presented in Table 8. Birth BW of the steers was not affected $(P=0.75)$ by different fatty acid profile of maternal supplements. However, weaning BW of the steers from CON dams was $11 \mathrm{~kg}$ greater $(P=0.05)$, which led to a tendency $(P=$ $0.06)$ for CON steers to have greater pre-weaning ADG compared to the steers from PUFA dams.

\section{mRNA expression in Longissimus muscle}

Relative mRNA expression of the genes that regulate early development of muscle and adipose tissue in LM is presented in Table 9. There were treatment $\times$ time interactions $(P \leq 0.04)$ for the mRNA expression of $M Y H 7$ and $C / E B P \beta$. The mRNA expression of $M Y H 7$ and $C / E B P \beta$ increased to a greater extent from birth to weaning for PUFA steers compared to CON. The expression of MYF5 tended $(P=0.07)$ to decrease more from birth to weaning for CON steers compared to PUFA. The expression of MYOG tended $(P=0.08)$ to be greater in CON steers than in PUFA steers at both birth and weaning. From birth to weaning, the expression of MYH1, MYH2, MYF6, MYOD1, C/EBPa, ZFP423, FABP4, PPARG, and $P P A R G C 1 A$ were increased $(P \leq 0.02)$ in $L M$. However, the expressions of $P A X 7$ and MEF2C decreased from birth to weaning $(P<0.01)$.

\section{mRNA expression in subcutaneous adipose tissue}

Relative mRNA expression of the genes that regulate the development of adipose tissue in subcutaneous tissue is presented in Table 10. Maternal supplementation of CON increased $(P=0.02)$ the mRNA expression of ZFP423 in the steer progeny at both birth and weaning compared to maternal supplementation of PUFA. mRNA expression of $C / E B P \beta$ tended $(P=0.08)$ to decrease to a greater extent from birth to weaning for CON compared to PUFA steers. However, mRNA expression of $S C D$ tended $(P=$ $0.08)$ to decrease to a greater extent from birth to weaning for PUFA compared to CON steers. From birth to weaning, the expression of C/EBPa, PPARGC1A, FASN, SREBP1, and ACACA were decreased $(P \leq 0.02)$ in subcutaneous adipose tissue.

\section{Discussion}

Forage availability between treatments during supplementation period did not differ, and cow/calf pairs were comingled and managed as a common group following supplementation period. Therefore, any differences in animal responses would be attributed to different fatty acid profile in the maternal supplements during late gestation.

\section{Cow performance}


Relative concentrations of plasma fatty acids were modified by supplements correspondingly with the fatty acid profile in the supplements, which indicates that fatty acid supplementation successfully modified the circulating fatty acids in cow plasma. In addition, supplementing Ca salts of fatty acids 3 times/wk has been documented to result in stable circulating fatty acid concentrations [29]. Essential fatty acids circulating in maternal plasma become available to the developing fetus after being transferred across the placenta [10]. In the current study, EFAs like ALA and C20:3n- 6 were increased in CON dams at calving, while EPA and DHA were increased in PUFA dams throughout the supplementation period. Similarly, other studies that have supplemented dams with different fat sources reported modified circulation of fatty acids corresponding with the feeding source [3,30,31]. In addition, EFAs supplemented to dairy cows during transition period were found elevated in skeletal muscle and fat tissues of neonate calves [32], which also demonstrates the potential effects of maternal EFAs on progeny muscle and adipose development. It is recognized that maternal circulating EFAs like linoleic acid, ALA, arachidonic acid, and DHA can modulate fetal growth and development [33]. However, BW and BCS of the cows were not affected by different fatty acid profile in supplements. This is consistent with previous studies that supplemented cows in an isocaloric and isonitrogenous manner [2,34].

Milk production was not affected by different fatty acid profiles in late gestation supplements. Cows from both treatments produced approximately $9 \mathrm{~kg} / \mathrm{d}$ of milk at $64 \pm 9 \mathrm{~d}$ after calving. For milk composition, the only difference was milk from PUFA dams had greater concentration of DHA in milk fat. All fatty acids that have 18 or longer chain are derived from preformed fatty acids from circulating plasma lipids [35], which means increased concentration of DHA in milk of PUFA cows should originate from absorption or reserves. Given that milk samples were collected approximately 60 days after supplementation, the increased concentration of DHA could be due to mobilization of reserves during negative energy balance, which was supported by decreased BCS from calving to Al pregnancy determination. However, this difference was minor because of the low concentration of DHA in milk from both treatments. Consistent with our results in milk evaluations, late gestation supplementation of fatty acids did not change either milk yield or composition in ewes [11]. However, it was also reported that late gestation of EPA + DHA did not change EPA or DHA concentrations in ewes' milk at $30 \mathrm{~d}$ after parturition [3]. The possible reasons for no differences in EPA or DHA concentrations in ewes could be low supplementation levels and tissue storage of fatty acids were depleted after $30 \mathrm{~d}$ of supplementation. In addition, milk production was not affected by fat supplementation during the last $62 \mathrm{~d}$ of gestation of primiparous beef cows [36]. No differences in milk production and composition were expected for the current study, as supplementation was terminated at calving and the WSW and milk sampling were conducted $64 \mathrm{~d}$ after supplementation.

Reproductive performance of the cows was not statistically different between cows fed different fatty acid supplements in late gestation. However, authors acknowledge that the current study is not powered for reproductive performance. Research that investigated prepartum fat supplementation have reported varied responses on reproductive performances. Heifers fed late gestation fat supplementation had increased subsequent pregnancy rates [34,37], especially under situations with limited forage availability. Supplementation was terminated at calving in the current study, and forage availability was sufficient 
before breeding season, which together could be the reason for no differences. Improvement in reproductive performance were commonly reported when the fat supplementation takes place during postpartum [38-40], in which fat supplementation, especially EFAs, could have impacts on the balance of reproductive hormones $[41,42]$. Studies with greater number of animals are needed for detecting differences in reproductive performance of cows supplemented with different fatty acid profile during late gestation.

\section{Calf performance}

It has been well recognized that environmental factors including maternal nutrition affect the growth and development of the subsequent progeny $[13,43,44]$. Recent promising effects including greater finishing phase growth performance, greater hot carcass weight and marbling score in beef cattle [2] and greater finished BW in sheep [4] indicate positive fetal programming potential of maternal fatty acid supplementation during late gestation. The development of skeletal muscle and adipose tissue is important for beef cattle. However, the mechanisms of maternal supplementation differing in fatty acid profile affecting the transcription of critical genes in muscle and adipose tissue have not been investigated in beef cattle.

Birth BW of the steers was not affected by maternal supplementation differing in fatty acid profile, despite relative concentrations of calf plasma fatty acids at birth being modified by treatments. Steers from CON dams had greater concentrations of C16:1c9, C18:1c9, ALA, and C20:3n-6, while PUFA steers had greater concentrations of EPA and DHA. In sheep, oleic acid tended to be greater in lambs from dams that had palmitic acid enriched supplementation during late gestation, while no differences were detected for ALA, EPA, or DHA [3]. However, in the current study, greater plasma concentrations of C18:1c9 and ALA in CON calves, C20:3n-6, EPA, and DHA in PUFA calves were consistent with corresponding concentrations in their dams. No difference in birth BW of progeny is consistent with previous studies that supplemented ruminant dams with isocaloric and isonitrogenous rumen-protected saturated/monounsaturated fatty acids or PUFA [2,11], sunflower seeds high in LA [45,46], and safflower seeds, raw soybeans, or sunflower seeds [34] during late gestation.

Despite no differences in birth BW and dam milk yield, CON steers had greater weaning BW and tended to have greater pre-weaning ADG compared to PUFA steers. Steer response to the greater milk DHA in PUFA should be limited as the concentration of DHA was extremely low in milk. Inconsistent with the current study, studies have reported that pre-weaning performance of the calves or lambs from dams supplemented with either palm fatty acid distillate or PUFA was not different $[2,11]$. Previous studies [2, 11] have used both sexes but neither reported treatment $\times$ sex interactions. Thus, authors do not believe the difference in results was due to this study using only male calves. Having different outcomes could also be due to different calving systems and supplementation rates. In Marques et al. [7], cows were under a spring-calving system and were fed $10.1 \mathrm{~kg} / \mathrm{cow}$ grass-alfalfa hay as their basal diet; and in Coleman et al [11], ewes were limit-fed a mixed ration in pens. While in the current study, fall-calving cows were grazing on abundant tall-fescue pastures. Compared to Marques et al. [7], cows in the current study 
were exposed to greater temperatures (July to September for the late gestation), which could potentially cause heat stress to the cows and lead to negative programming effects on the subsequent lactation of the dams, postnatal growth performance and immune function of the offspring [47]. Additionally, it is reported that ergot alkaloids found in endophyte tall-fescue can cause vasoconstriction in grazing animals [48], which could potentially impact the fatty acid circulation and transferring to the fetus in the current study. Compared to $190 \mathrm{~g} / \mathrm{d}$ of Prequel/Strata in Marques et al. [7], $160 \mathrm{~g} / \mathrm{d}$ of Prequel/Strata were fed to cows in the current study. The ratio of Prequel to Strata in the two studies was the same, while the concentration of EPA + DHA (33.3\%) in Strata of Marques et al. [7] was greater than the current study (18.5\%) and the product label (16\% minimum). This resulted in $26 \mathrm{~g} / \mathrm{d}$ of EPA/DHA delivered to cows in Marques et al. [7] and $10.5 \mathrm{~g} / \mathrm{d}$ in the current study.

During late gestation, restriction of maternal nutrition reduces muscle fiber size, but has little impact on muscle fiber number $[49,50]$. However, nutritional deficiency during late gestation reduces the density of satellite cells, which could also negatively affect postnatal muscle growth [51]. Therefore, it is important to provide reasonable nutrients for optimal fetal muscle development and subsequent postnatal growth performance. According to the mRNA expression analysis on muscle and subcutaneous adipose tissue collected at birth and weaning, myogenesis and adipogenesis of the steers could be modified by maternal supplements.

In longissimus muscle, there tended to be a treatment $x$ time interaction for the mRNA expression of MYF5, in which CON steers had the greatest expression of MYF5 at birth. The increase in expression of MYF5 activates all other myogenic regulatory factors (MYOD, MYOG and MYF6) [52]. It was documented that MYF5 is directly regulated by $P A X 7$, and transcription of MYF5 varies dependent on the levels of $P A X 7[53,54]$. In the current study, no treatment or treatment $\times$ time effect was detected for the expression of PAX7. Other factors like signals of the Wingless and Int family and Sonic hedgehog also directly induce MYF5 expression [55], but are more important during early embryonic stage [52]. The tendency of greater expression of MYF5 at birth in CON steers indicates they potentially had greater myogenesis in LM in the neonatal stage. Greater myogenesis in CON steers was also supported by the tendency of having greater expression of $M Y O G$ in LM. Gene MYOD is an early myogenic marker, which is critical in regulating the maturation of secondary muscle fibers [56]. The current study also indicates MYOG was downregulated by maternal supplementation of PUFA compared to CON. Inconsistent with our finding for MYOG, Brandão et al. [5] reported that the expression of MYOG in LM at birth was greater in calves from dams supplemented with Ca salts of soybean oil than those from dams supplemented with saturated fat. However, Brandão et al. [5] did not find any differences on offspring growth performance during preweaning period. Studies on $\mathrm{C} 2 \mathrm{C} 12$ myoblasts $[57,58]$ indicate that overdosage of EPA and DHA could inhibit myogenesis and down-regulate myogenic genes, including MYOG, MYF6, MYOD, and PAX7. The supplementation level of EPA and DHA $(10.5 \mathrm{~g} / \mathrm{d})$ in current study should not have resulted in overdosage. However, results from this study indicate the development of secondary muscle fibers in CON steers could be greater during pre-weaning period compared to PUFA steers. Mechanism for PUFA steers having lower mRNA expression of MYF5 and MYOD than CON needs further investigation. In muscle, MYH1, MYH2, and MYH7 are associated with myosin heavy chains IIx, Ila, and I, respectively [59]. 
Myosin heavy chain I is a slow isoform also called beta-myosin heavy chain. The expression of $M Y H 7$ was detected in developing muscles of embryo and fetus, and in type 1 muscle fibers and ventricles in adults [60]. There was a treatment $\times$ time interaction detected for the expression of $M Y H 7$, which indicates the formation of myosin heavy chain I in PUFA steers was slow at birth and increased at time of weaning.

Intramuscular fat is key for palatability of beef because it contributes to flavor and juiciness [13]. The sequential adipogenesis in different depots provides an opportunity to specifically enhance the intramuscular adipocyte formation during late gestation, neonatal stage, and early postnatal stage (earlier than $250 \mathrm{~d}$ of age) [50]. Nutritional manipulations, like maternal supplementation of nutrients or bioactive compounds, during these time windows are expected to be able to modify intramuscular adipogenesis $[13,61]$. The mRNA expression of $C A A T /$ enhancer binding protein $\beta(C / E B P \beta)$ in LM was affected by the treatment $\times$ time interaction, in which the expression increased to a greater extent from birth to weaning for PUFA compared to CON steers. The essential genes that regulate adipogenesis include $C / E B P a, C / E B P \beta, P P A R Y, Z F P 423$, and $F A B P 4$ [57]. The transcription factors $C / E B P \beta$ and $\delta$ are induced by adipogenic stimuli at the initiation of adipogenesis, which then lead to the expression of $P P A R Y$ [62]. For adipogenesis, $P P A R Y$ is essential and indispensable [63]. Therefore, $C / E B P \beta$ is critical for early stage of adipocyte differentiation. Our data indicates that the intramuscular adipocyte differentiation could be increased at weaning by maternal supplementation of PUFA during late gestation, which might lead to greater formation of marbling. However, further research following steers all the way to slaughter is still needed.

Subcutaneous fat is not desirable, because it negatively impacts feed efficiency and devalues the carcass [64]. Research investigating fat supplementation on lipid metabolism of ewes [3], lambs [65], dairy cows [66], and young bulls [67] has been conducted, but the effect of maternal fat supplementation on lipid metabolism in offspring tissues is scarcely studied. Zinc-finger protein 423 was reported to induce PPARY expression and the adipogenic commitment of progenitor cells [68]. Increased expression of ZFP423 in CON steers at birth and weaning indicates greater adipogenic commitment in subcutaneous adipose tissue, which might lead to greater $12^{\text {th }}$ rib fat thickness and negatively affect feed efficiency and carcass yield grade. The $12^{\text {th }}$ rib fat of the calves was not affected by maternal supplementation of calcium salts of PUFA during late gestation under a spring-calving system [7]. The current study did not measure $12^{\text {th }}$ rib fat thickness at weaning, and further research is needed to investigate maternal fat supplementation of different fatty acid profile on $12^{\text {th }}$ rib fat thickness of the carcass at slaughter. Adipogenesis is triggered when $P P A R G$ is activated by $C / E B P \beta$ and $C / E B P \delta$ [64]. Stearoyl-CoA desaturase $(S C D)$ is required for the biosynthesis of monounsaturated fatty acids [69]. Mature SREBP1 activates transcription of FASN and $S C D$ [69]. Treatment $\times$ time interaction detected for $C / E B P \beta$ and $S C D$ in the current study might indicate modified adipogenesis by maternal supplementations differing in fatty acid profile. Coleman et al. [65] reported finishing lambs from dams fed EPA and DHA during late gestation had decreased hepatic mRNA expression of SCD compared to palm fatty acid distillate, while no effect on subcutaneous adipose mRNA expression of $S C D$ was detected. Further investigation is needed for the 
regulation of maternal fatty acid supplementation on mRNA expression of adipogenic genes and lipid metabolism in subcutaneous adipose tissue.

\section{Conclusions}

Late gestation supplementation with differing fatty acid profiles did not affect cow BW, BCS, or rebreeding pregnancy rates. For steer progeny, maternal supplementation enriched in saturated and monounsaturated fatty acids increased weaning BW compared to PUFA, which could be attributed to upregulated mRNA expression of myogenic genes during pre-weaning period, especially at birth. These findings encourage further investigation of maternal supplementation of different fatty acid profile on subsequent progeny growth and production performance and mRNA expression of myogenic and adipogenic genes under different production systems.

\section{Additional Files}

\section{Additional file 1}

Supplemental Table 1. GenBank accession number, sequence and amplicon size of primers used for mRNA expression by qPCR

Supplemental Table 2. Sequencing results of PCR products of designed primer

Supplemental Table 3. qPCR performance of the genes analyzed in Longissimus muscle

Supplemental Table 4. qPCR performance of the genes analyzed in adipose tissue

\section{Declarations}

\section{Ethics approval and consent to participate}

All the procedures for this study were conducted in accordance with a protocol approved by the Institutional Animal Care and Use Committee (IACUC) of the University of Illinois (protocol \#18109). Consent to participate not applicable.

\section{Consent for publication}

Not applicable.

\section{Availability of data and materials}

The datasets during and/or analyzed during the current study are available from the corresponding authors on reasonable request. 
The authors declare that they have no competing interests.

\section{Funding}

Not applicable.

\section{Authors' contributions}

TS and DWS conceived and designed the experiments; FAI managed the experimental animals and helped with data collection; TS and JCM performed the analysis of mRNA expression. TS performed data collection, statistical analysis and wrote the manuscript. All authors read and approved the final version of the manuscript.

\section{Acknowledgements}

The authors would like to thank Virtus Nutrition LLC for providing the products of calcium salts of fatty acids (EnerGII, Strata, and Prequel) and covering the cost of the fatty acid profile analysis for feed and milk samples. We thank Dr. Kevin Murphy and Dr. Alejandro Relling for providing suggestions on experimental design. We thank the staff at the University of Illinois Dixon Springs Agricultural Center, Simpson, IL, for care of the experimental animals and aiding in collection of data. We also thank lab technician James Hartman, graduate students, and undergraduate students for help on data collection and laboratory analysis.

\section{Authors' information}

Taoqi Shao is PhD candidate, Department of Animal Sciences, University of Illinois, Urbana, Illinois, 61801, USA. Frank A. Ireland was manager of the University of Illinois Dixon Springs Agricultural Center, Simpson, Illinois, 62985, USA. Joshua C. McCann is assistant professor in the Department of Animal Sciences, University of Illinois, Urbana, Illinois, 61801, USA. Daniel W. Shike is associate professor in the Department of Animal Sciences, University of Illinois, Urbana, Illinois, 61801, USA.

\section{Abbreviations}

ADF: acid detergent fiber; ALA: alpha-linolenic acid; FAME: fatty acid methyl esters; ADG: average daily gain; Al: artificial insemination; BCS: body condition score; BW: body weight; CON: supplement rich in saturated and monounsaturated fatty acids; CP: crude protein; DHA: docosahexaenoic acid; EFAs: essential fatty acids; DM: dry matter; EPA: eicosapentaenoic acid; EPD: expected progeny differences; HCW: hot carcass weight; LM: longissimus muscle; MUN: milk urea nitrogen; NCBI: National Center for Biotechnology Information database; NDF: neutral detergent fiber; PUFA: supplement rich in polyunsaturated fatty acids; qPCR: quantitative PCR; WSW: weigh-suckle-weigh.

\section{References}


1. Nathanielsz PW, Poston L, Taylor PD. In utero exposure to maternal obesity and diabetes: animal models that identify and characterize implications for future health. Clin Perinatol. 2007;34:515-26.

2. Marques RS, Cooke RF, Rodrigues MC, Brandão AP, Schubach KM, Lippolis KD, et al. Effects of supplementing calcium salts of polyunsaturated fatty acids to late-gestating beef cows on performance and physiological responses of the offspring. J Anim Sci. 2017;95:5347-57.

3. Coleman DN, Murphy KD, Relling AE. Prepartum fatty acid supplementation in sheep. II. supplementation of eicosapentaenoic acid and docosahexaenoic acid during late gestation alters the fatty acid profile of plasma, colostrum, milk and adipose tissue, and increases lipogenic gene expression. J Anim Sci. 2018;96:1181-204.

4. Martin CC, Coleman DN, Garcia LG, Furnus CC, Relling AE. Prepartum fatty acid supplementation in sheep. III. Effect of eicosapentaenoic acid and docosahexaenoic acid during finishing on performance, hypothalamus gene expression, and muscle fatty acids composition in lambs. J Anim Sci. 2018;96:5300-10.

5. Brandão AP, Cooke RF, Schubach KM, Rett B, Souza OA, Schachtschneider CL, et al. Supplementing Ca salts of soybean oil to late-gestating beef cows: impacts on performance and physiological responses of the offspring. J Anim Sci. 2020;98:1-12.

6. Jacometo CB, Osorio JS, Socha M, Corrêa MN, Piccioli-Cappelli F, Trevisi E, et al. Maternal consumption of organic trace minerals alters calf systemic and neutrophil mRNA and microRNA indicators of inflammation and oxidative stress. J Dairy Sci. 2015;98:7717-29.

7. Jacometo CB, Zhou Z, Luchini D, Trevisi E, Corrêa MN, Loor JJ. Maternal rumen-protected methionine supplementation and its effect on blood and liver biomarkers of energy metabolism, inflammation, and oxidative stress in neonatal Holstein calves. J Dairy Sci. 2016;99:6753-63.

8. Alharthi AS, Coleman DN, Liang Y, Batistel F, Elolimy AA, Yambao RC, et al. Hepatic 1-carbon metabolism enzyme activity, intermediate metabolites, and growth in neonatal Holstein dairy calves are altered by maternal supply of methionine during late pregnancy. J Dairy Sci. 2019;102:10291303.

9. Shingfield KJ, Bonnet M, Scollan ND. Recent developments in altering the fatty acid composition of ruminant-derived foods. Animal. 2013;7:132-62.

10. Noble RC, Shand JH, Drummond JT, Moore JH. "Protected" polyunsaturated fatty acid in the diet of the ewe and the essential fatty acid status of the neonatal lamb. J Nutr. 1978;108:1868-76.

11. Coleman DN, Rivera-Acevedo KC, Relling AE. Prepartum fatty acid supplementation in sheep I. Eicosapentaenoic and docosahexaenoic acid supplementation do not modify ewe and lamb metabolic status and performance through weaning. J Anim Sci. 2018;96:364-74.

12. Rosa Velazquez M, Batistel F, Pinos Rodriguez JM, Relling AE. Effects of maternal dietary omega-3 polyunsaturated fatty acids and methionine during late gestation on fetal growth, DNA methylation, and $m R N A$ relative expression of genes associated with the inflammatory response, lipid metabolism and DNA methylation in. J Anim Sci Biotechnol. 2020;11:111. 
13. Du M, Wang B, Fu X, Yang Q, Zhu MJ. Fetal programming in meat production. Meat Sci. 2015;109:40-7.

14. Xu HE, Lambert MH, Montana VG, Parks DJ, Blanchard SG, Brown PJ, et al. Molecular recognition of fatty acids by peroxisome proliferator-activated receptors. Mol Cell. 1999;3:397-403.

15. Thoennes SR, Tate PL, Price TM, Kilgore MW. Differential transcriptional activation of peroxisome proliferator-activated receptor gamma by omega-3 and omega- 6 fatty acids in MCF-7 cells. Mol Cell Endocrinol. 2000;160:67-73.

16. Clarke SD. Polyunsaturated fatty acid regulation of gene transcription: A molecular mechanism to improve the metabolic syndrome. J Nutr. 2001;131:1129-32.

17. Hiller B, Hocquette JF, Cassar-Malek I, Nuernberg G, Nuernberg K. Dietary n-3 PUFA affect lipid metabolism and tissue function-related genes in bovine muscle. Br J Nutr. 2012;108:858-63.

18. Moon RJ, Harvey NC, Robinson SM, Ntani G, Davies JH, Inskip HM, et al. Maternal plasma polyunsaturated fatty acid status in late pregnancy is associated with offspring body composition in childhood. J Clin Endocrinol Metab. 2013;98:299-307.

19. Vidakovic, A.J., Gishti, O., Voortman, T., Felix, J.F., Williams, M.A., Hofman, A., Demmelmair, H., Koletzko, B., Tiemeier, H., Jaddoe, V.W. and Gaillard R. Maternal plasma PUFA concentrations during pregnancy and childhood adiposity: The Generation R Study. Am J Clin Nutr. 2016;103:1017-25.

20. Hidaka, B.H., Thodosoff, J.M., Kerling, E.H., Hull, H.R., Colombo, J. and Carlson SE. Intrauterine DHA exposure and child body composition at $5 \mathrm{y}$ : Exploratory analysis of a randomized controlled trial of prenatal DHA supplementation. Am J Clin Nutr. 2018;107:35-42.

21. Barnhart SK. Estimating available pasture forage. lowa State University, University Extension; 2009.

22. Larson JE, Lamb GC, Stevenson JS, Johnson SK, Day ML, Geary TW, et al. Synchronization of estrus in suckled beef cows for detected estrus and artificial insemination and timed artificial insemination using gonadotropin-releasing hormone, prostaglandin F2a, and progesterone1. J Anim Sci. 2006;84:332-42.

23. Pizarro C, Arenzana-Rámila I, Pérez-del-Notario N, Pérez-Matute P, González-Sáiz JM. Thawing as a critical pre-analytical step in the lipidomic profiling of plasma samples: New standardized protocol. Anal Chim Acta. 2016;912:1-9.

24. Beal WE, Notter DR, Akers RM. Techniques for estimation of milk yield in beef cows and relationships of milk yield to calf weight gain and postpartum reproduction. J Anim Sci. 1990;68:937-43.

25. Hara A, Radin NS. Lipid extraction of tissues with a low-toxicity solvent. Anal Biochem. 1978;90:4206.

26. Chouinard PY, Corneau L, Barbano DM, Metzger LE, Bauman DE. Conjugated linoleic acids alter milk fatty acid composition and inhibit milk fat secretion in dairy cows. J Nutr. 1999;129:1579-84.

27. Sukhija PS, Palmquist DL. Rapid method for determination of total fatty acid content and composition of feedstuffs and feces. J Agric Food Chem. 1988;36:1202-6. 
28. Bionaz M, Loor JJ. Gene networks driving bovine milk fat synthesis during the lactation cycle. BMC Genomics. 2008;9:366.

29. Cook EK, Garcia-Ascolani ME, Ricks RE, Duckett SK, Lamb GC, Dilorenzo N, et al. The effect of frequency of supplementing rumen-protected unsaturated fatty acids on blood serum fatty acid profiles in beef heifers and lactating cows. J Anim Sci. 2017;95:2977-85.

30. Lake SL, Weston TR, Scholljegerdes EJ, Murrieta CM, Alexander BM, Rule DC, et al. Effects of postpartum dietary fat and body condition score at parturition on plasma, adipose tissue, and milk fatty acid composition of lactating beef cows1. J Anim Sci. 2007;85:717-30.

31. Ricks RE, Cook EK, Long NM. Effects of supplementing ruminal-bypass unsaturated fatty acids during late gestation on beef cow and calf serum and colostrum fatty acids, transfer of passive immunity, and cow and calf performance. Appl Anim Sci. 2020;36:271-84.

32. Dahl N, Albrecht E, Dannenberger D, Uken KL, Hammon HM, Maak S. Consequences of maternal essential fatty acid and conjugated linoleic acid supplementation on the development of calf muscle and adipose tissue. Animals. 2020;10:1598.

33. Shrestha N, Sleep SL, Cuffe JS, Holland OJ, Perkins A V, Yu Yau S, et al. Role Of Omega-6 and Omega-3 fatty acids in fetal programming. Clin Exp Pharmacol Physiol. 2019;1-9.

34. Bellows RA, Grings EE, Simms DD, Geary TW, Bergman JW. Effects of feeding supplemental fat during gestation to first-calf beef heifers. Prof Anim Sci. 2001;17:81-9.

35. Chilliard Y, Ferlay A, Mansbridge RM, Doreau M. Ruminant milk fat plasticity: nutritional control of saturated, polyunsaturated, trans and conjugated fatty acids. Ann Zootech. 2000;49:181-205.

36. Alexander BM, Hess BW, Hixon DL, Garrett BL, Rule DC, McFarland M, et al. Influence of prepartum fat supplementation on subsequent beef cow reproduction and calf performance. Prof Anim Sci. 2002;18:351-7.

37. Funston RN. Fat supplementation and reproduction in beef females. J Anim Sci. 2004;82 ESuppl:154-61.

38. Espinoza JL, Ramirez-Godinez JA, Jimenez JA, Flores A. Effects of calcium soaps of fatty acids on postpartum reproductive activity in beef cows and growth of calves. J Anim Sci. 1995;73:2888.

39. Thomas MG, Bao B, Williams GL. Dietary fats varying in their fatty acid composition differentially influence follicular growth in cows fed isoenergetic diets. J Anim Sci. 1997;75:2512.

40. De Fries CA, Neuendorff DA, Randel RD. Fat supplementation influences postpartum reproductive performance in Brahman cows. J Anim Sci. 1998;76:864-70.

41. Mattos R, Staples CR, Thatcher WW. Effects of dietary fatty acids on reproduction in ruminants. Rev Reprod. 2000;5:38-45.

42. Burns PD, Bonnette TR, Engle TE, Whittier JC. Effects of fishmeal supplementation on fertility and plasma $\Omega-3$ fatty acid profiles in primiparous, lactating beef cows. Prof Anim Sci. 2002;18:373-9.

43. Godfrey KM, Barker DJ. Fetal programming and adult health. Public Health Nutr. 2001;4:611-24. 
44. Greenwood PL, Bell AW. Developmental Programming and Growth of Livestock Tissues for Meat Production. Vet. Clin. North Am. - Food Anim. Pract. 2019. p. 303-19.

45. Banta JP, Lalman DL, Owens FN, Krehbiel CR, Wettemann RP. Effects of interval-feeding whole sunflower seeds during mid to late gestation on performance of beef cows and their progeny. $J$ Anim Sci. 2006;84:2410-7.

46. Banta JP, Lalman DL, Owens FN, Krehbiel CR, Wettemann RP. Effects of prepartum supplementation of linoleic and mid-oleic sunflower seed on cow performance, cow reproduction, and calf performance from birth through slaughter, and effects on intake and digestion in steers. J Anim Sci. 2011;89:3718-27.

47. Tao S, Dahl GE, Laporta J, Bernard JK, Orellana Rivas RM, Marins TN. PHYSIOLOGY SYMPOSIUM: Effects of heat stress during late gestation on the dam and its calf. J Anim Sci. 2019;97:2245-57.

48. Strickland JR, Aiken GE, Spiers DE, Fletcher LR, Oliver JW. Physiological basis of fescue toxicosis. Tall Fescue Twenty-first Century, 53. 2009. p. 203-27.

49. Paul L. Greenwood, Ramona M. Slepetis AWB and JWH. Intrauterine growth retardation is associated with reduced cell cycle activity, but not myofibre number, in ovine fetal muscle. Reprod Fertil Dev. 1999;11:281-91.

50. Du M, Tong J, Zhao J, Underwood KR, Zhu M, Ford SP, et al. Fetal programming of skeletal muscle development in ruminant animals. J Anim Sci. 2010;88:E51-60.

51. Woo M, Isganaitis E, Cerletti M, Fitzpatrick C, Wagers AJ, Jimenez-Chillaron J, et al. Early life nutrition modulates muscle stem cell number: Implications for muscle mass and repair. Stem Cells Dev. 2011;20:1763-9.

52. Asfour HA, Allouh MZ, Said RS. Myogenic regulatory factors: The orchestrators of myogenesis after 30 years of discovery. Exp Biol Med. 2018;243:118-28.

53. McKinnell IW, Ishibashi J, Le Grand F, Punch VGJ, Addicks GC, Greenblatt JF, et al. Pax7 activates myogenic genes by recruitment of a histone methyltransferase complex. Nat Cell Biol. 2008;10:7784.

54. Soleimani VD, Punch VG, Kawabe Y ichi, Jones AE, Palidwor GA, Porter CJ, et al. Transcriptional dominance of PAX7 in adult myogenesis is due to high-affinity recognition of homeodomain motifs. Dev Cell. 2012;22:1208-20.

55. Tajbakhsh S, Borello U, Vivarelli E, Kelly R, Papkoff J, Duprez D, et al. Differential activation of Myf5 and MyoD by different Wnts in explants of mouse paraxial mesoderm and the later activation of myogenesis in the absence of Myf5. Development. 1998. p. 4155-62.

56. Hasty P, Bradley A, Morris JH, Edmondson DG, Venutit JM, Olson EN, et al. Muscle deficiency and neonatal death in mice with a targeted mutation in the myogenin gene. Nature. 1993;364:501-6.

57. Hsueh TY, Baum JI, Huang Y. Effect of eicosapentaenoic acid and docosahexaenoic acid on myogenesis and mitochondrial biosynthesis during murine skeletal muscle cell differentiation. Front Nutr. 2018;5. 
58. Zhang J, Xu X, Liu Y, Zhang L, Odle J, Lin X, et al. EPA and DHA inhibit myogenesis and downregulate the expression of muscle-related genes in C2C12 myoblasts. Genes (Basel). 2019;10:64.

59. Clark DL, Boler DD, Kutzler LW, Jones KA, McKeith FK, Killefer J, et al. Muscle gene expression associated with increased marbling in beef cattle. Anim Biotechnol. 2011;22:51-63.

60. Schiaffino S, Rossi AC, Smerdu V, Leinwand LA, Reggiani C. Developmental myosins: Expression patterns and functional significance. Skelet. Muscle. 2015. p. 1-14.

61. M. Du, Y. Huang, A. K. Das, Q. Yang, M. S. Duarte, M. V. Dodson M-JZ. Meat Science and Muscle Biology Symposium: Manipulating mesenchymal progenitor cell differentiation to optimize performance and carcass value of beef cattle. J Anim Sci. 2013;91:1419-27.

62. Fajas L, Debril MB, Auwerx J. Peroxisome proliferator-activated receptor- $ү$ : From adipogenesis to carcinogenesis. J Mol Endocrinol. 2001;27:1-9.

63. Rosen ED, MacDougald OA. Adipocyte differentiation from the inside out. Nat Rev Mol Cell Biol. 2006;7:885-96.

64. Soret B, Mendizabal JA, Arana A, Alfonso L. Expression of genes involved in adipogenesis and lipid metabolism in subcutaneous adipose tissue and longissimus muscle in low-marbled Pirenaica beef cattle. Animal. 2016;10:2018-26.

65. Coleman DN, Martin ACC, Jin Y, Lee K, Relling AE. Prepartum fatty acid supplementation in sheep. IV. Effect of calcium salts with eicosapentaenoic acid and docosahexaenoic acid in the maternal and finishing diet on lamb liver and adipose tissue during the lamb finishing period. J Anim Sci. 2019;97:3071-88.

66. Elis S, Desmarchais A, Freret S, Maillard V, Labas V, Cognié J, et al. Effect of a long-chain n-3 polyunsaturated fatty acid - enriched diet on adipose tissue lipid profiles and gene expression in Holstein dairy cows. J Dairy Sci. 2016;99:10109-27.

67. Corazzin M, Bovolenta S, Saccà E, Bianchi G, Piasentier E. Effect of linseed addition on the expression of some lipid metabolism genes in the adipose tissue of young Italian Simmental and Holstein bulls. J Anim Sci. 2013;91:405-12.

68. Gupta RK, Arany Z, Seale P, Mepani RJ, Ye L, Conroe HM, et al. Transcriptional control of preadipocyte determination by Zfp423. Nature. 2010;464:619-23.

69. Paton CM, Ntambi JM. Biochemical and physiological function of stearoyl-CoA desaturase. Am. J. Physiol. - Endocrinol. Metab. 2009. p. 28-37.

\section{Tables}

Table 1. Supplement composition and nutrient intake from treatment supplements containing Ca salts of saturated/monounsaturated fatty acids (CON) or polyunsaturated fatty acids (PUFA) 


\begin{tabular}{lll}
\hline Item (Dry matter basis) & CON $^{1}$ & PUFA $^{2}$ \\
\hline Ingredients, kg/cow/d & & \\
Soybean hull & 0.77 & 0.77 \\
EnerGII & 0.155 & 0 \\
Prequel & 0 & 0.08 \\
Strata & 0 & 0.08 \\
Macronutrient intake, kg/cow/d & & \\
Dry matter & 0.9 & 0.9 \\
Crude protein & 0.07 & 0.07 \\
Total fat & 0.16 & 0.15 \\
Fatty acid intake, g/d & & \\
C16:0 & 57.86 & 14.43 \\
C18:0 & 5.74 & 6.97 \\
C18:1c9 & 44.69 & 24.41 \\
C18:2n-6 & 13.60 & 33.24 \\
C18:3n-3 & 1.32 & 2.24 \\
C20:5n-3 & 0 & 6.41 \\
C22:6n-3 & 0 & 4.12 \\
\hline
\end{tabular}

${ }^{1} \mathrm{CON}=$ cows were supplemented soybean hulls mixed with $155 \mathrm{~g} \mathrm{DM} / \mathrm{cow} / \mathrm{d}$ EnerGII (Virtus Nutrition LLC, Corcoran, CA) for $77 \pm 6$ days prepartum

${ }^{2}$ PUFA $=$ cows were supplemented soybean hulls mixed with $80 \mathrm{~g} \mathrm{DM} / \mathrm{cow} / \mathrm{d}$ Strata $+80 \mathrm{~g}$ DM/cow/d Prequel (Virtus Nutrition LLC, Corcoran, CA) for $77 \pm 6$ days prepartum

Table 2. Nutritional and fatty acid profile of ingredients fed to cows during late gestation ${ }^{1}$

\begin{tabular}{llllll}
\hline Item (Dry matter basis) & Forage & Soybean hull & EnerGII & Prequel & Strata \\
\hline Dry matter, \% & 29.3 & 85.1 & 96.4 & 95.3 & 95.7 \\
Crude protein, \% & 12.7 & 9.6 & 0 & 0 & 0 \\
Neutral detergent fiber, \% & 56.6 & 71.7 & - & - & - \\
Acid detergent fiber, \% & 35.2 & 51.8 & - & - & - \\
Total fat, \% & 3.4 & 2.3 & 94.3 & 83.7 & 83.0 \\
Total fatty acid, \% & 1.5 & 1.0 & 77.2 & 74.4 & 67.3 \\
Fatty acid profile, \% of total fatty acid & & & & \\
C16:0 & 20.35 & 17.2 & 47.2 & 0.40 & 23.8 \\
C18:0 & 2.32 & 7.68 & 4.28 & 3.88 & 7.52 \\
C18:1c9 & 4.62 & 14.1 & 36.4 & 27.8 & 12.5 \\
C18:2n-6 & 20.13 & 38.6 & 8.78 & 49.1 & 1.72 \\
C18:3n-3 & 40.07 & 12.2 & 0.29 & 1.27 & 0.94 \\
C20:5n-3 & 0 & 0 & 0 & 0 & 11.9 \\
C22:6n-3 & 0 & 0 & 0 & 0 & 7.66 \\
\hline
\end{tabular}

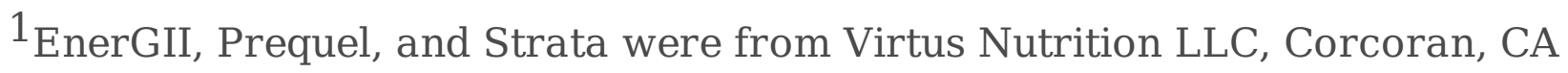


Table 3. Effects of late gestation supplementation of Ca salts of saturated/monounsaturated fatty acids (CON) or polyunsaturated fatty acids (PUFA) on relative concentrations of selected plasma fatty acids in cows ${ }^{1}$

\begin{tabular}{lcccccccc}
\hline Item & \multicolumn{2}{c}{ Mid-sup $^{2}$} & \multicolumn{2}{c}{ At-calving $^{3}$} & SEM & \multicolumn{3}{c}{$P$-values } \\
\cline { 2 - 3 } & CON $^{4}$ & PUFA $^{5}$ & CON & PUFA & & Trt & time & Trt $\times$ time \\
\hline C15:0 & 39.6 & 42.1 & 27.4 & 31.8 & 1.95 & 0.15 & $<0.01$ & 0.58 \\
C16:0 & 1257 & 1183 & 1380 & 1362 & 58.1 & 0.44 & 0.04 & 0.65 \\
C16:1c9 & 10.2 & 16.1 & 28.4 & 35.7 & 4.95 & 0.12 & $<0.01$ & 0.86 \\
C17:0 & 62.2 & 61.6 & 49.0 & 59.0 & 4.60 & 0.27 & 0.11 & 0.26 \\
C18:0 & 1387 & 1396 & 1009 & 1048 & 49.8 & 0.70 & $<0.01$ & 0.63 \\
C18:1c9 & 961 & 800 & 1225 & 1077 & 92.4 & 0.09 & 0.03 & 0.95 \\
C18:2n-6 & 1190 & 1176 & 751 & 875 & 50.7 & 0.39 & $<0.01$ & 0.11 \\
C18:3n-3 & $262^{\mathrm{a}}$ & $252^{\mathrm{a}}$ & $173^{\mathrm{b}}$ & $98^{\mathrm{c}}$ & 20.9 & 0.08 & $<0.01$ & 0.05 \\
C20:0 & 2.7 & 4.4 & 3.1 & 4.5 & 0.38 & $<0.01$ & 0.61 & 0.78 \\
C20:3n-6 & 141 & 89 & 96 & 73 & 13.0 & 0.05 & $<0.01$ & 0.07 \\
C20:4n-6 & $195^{\mathrm{a}}$ & $213^{\mathrm{a}}$ & $49^{\mathrm{b}}$ & $31^{\mathrm{c}}$ & 8.5 & 0.97 & $<0.01$ & 0.03 \\
C20:5n-37 & 40.2 & 93.2 & 33 & 57.5 & - & $<0.01$ & 0.03 & 0.50 \\
C22:6n-3 & 4.8 & 26.4 & 7.2 & 20.7 & 4.09 & 0.01 & 0.59 & 0.22 \\
\hline
\end{tabular}

${ }^{1}$ Data are presented as relative concentration per $100 \mathrm{ul}$ plasma to internal standard C23:0

2 Mid-supplementation was $d-42$ of the experiment

${ }^{3}$ At-calving plasma samples were collected from dams $5 \pm 2.4 \mathrm{~d}$ post-calving ${ }^{4} \mathrm{CON}=$ cows were supplemented soybean hulls mixed with $155 \mathrm{~g} \mathrm{DM} / \mathrm{cow} / \mathrm{d}$ EnerGII (Virtus Nutrition LLC, Corcoran, CA) for $77 \pm 6$ days prepartum

${ }^{5}$ PUFA = cows were supplemented soybean hulls mixed with $80 \mathrm{~g} \mathrm{DM} / \mathrm{cow} / \mathrm{d}$ Strata $+80 \mathrm{~g}$ DM/cow/d Prequel (Virtus Nutrition LLC, Corcoran, CA) for $77 \pm 6$ days prepartum ${ }^{6}$ Trt $=$ treatment effect; Trt $\times$ Time $=$ interaction between treatment and time

${ }^{7}$ Data were transformed for statistical analysis because of non-normal distribution; Means are presented after back-transformation

Table 4. Effects of late gestation supplementation of Ca salts of saturated/monounsaturated fatty acids (CON) or polyunsaturated fatty acids (PUFA) on relative concentrations of selected plasma fatty acids in steers at birth ${ }^{1}$ 


\begin{tabular}{lcccc}
\hline & CON $^{2}$ & PUFA $^{3}$ & SEM & $P$-value \\
Item & & & & \\
\hline C15:0 & 21.7 & 19.2 & 2.14 & 0.29 \\
C16:0 & 1101 & 1030 & 104.1 & 0.53 \\
C16:1c9 & 23.4 & 15.0 & 1.77 & 0.01 \\
C17:0 & 28.6 & 27.5 & 2.47 & 0.69 \\
C18:0 & 1036 & 1021 & 64.0 & 0.83 \\
C18:1c9 & 1132 & 881 & 40.4 & $<0.01$ \\
C18:2n-6 & 772 & 855 & 67.4 & 0.27 \\
C18:3n-3 & 176 & 98 & 12.2 & $<0.01$ \\
C20:0 & 3.6 & 4.3 & 0.48 & 0.20 \\
C20:3n-6 & 48.4 & 31.7 & 3.06 & $<0.01$ \\
C20:4n-6 & 146 & 138 & 13.0 & 0.58 \\
C20:5n-3 & 36.3 & 56.7 & 5.22 & 0.01 \\
C22:6n-3 & 9.0 & 18.8 & 4.78 & 0.09 \\
\hline
\end{tabular}

${ }^{1}$ Data are presented as relative concentration per 100 ul plasma to internal standard C23:0 ${ }^{2} \mathrm{CON}=$ cows were supplemented soybean hulls mixed with $155 \mathrm{~g} \mathrm{DM} / \mathrm{cow} / \mathrm{d}$ EnerGII (Virtus Nutrition LLC, Corcoran, CA) for $77 \pm 6$ days prepartum ${ }^{3}$ PUFA $=$ cows were supplemented soybean hulls mixed with $80 \mathrm{~g} \mathrm{DM} / \mathrm{cow} / \mathrm{d}$ Strata $+80 \mathrm{~g}$ DM/cow/d Prequel (Virtus Nutrition LLC, Corcoran, CA) for $77 \pm 6$ days prepartum

Table 5. Effects of fatty acid supplementation on cow body weight and body condition score $^{1}$

\begin{tabular}{lllll}
\hline Item & CON $^{2}$ & PUFA $^{3}$ & SEM & $P$-value \\
\hline Cow BW, kg & & & & \\
Initial (d -77) & 604 & 597 & 12.4 & 0.62 \\
Mid supplementation (d -42) & 642 & 632 & 12.6 & 0.43 \\
Pre calving (d -18) & 652 & 642 & 12.7 & 0.46 \\
Calving (5 \pm 2.4 d post-calving) & 597 & 589 & 13.1 & 0.57 \\
AI (d 78) & 610 & 595 & 14.5 & 0.34 \\
AI pregnancy determination (d 133) & 597 & 587 & 15.6 & 0.52 \\
Weaning (d 186) & 540 & 526 & 14.5 & 0.39 \\
Cow BCS & & & & \\
Initial & 6.2 & 6.2 & 0.14 & 0.89 \\
Mid supplementation & 6.3 & 6.4 & 0.13 & 0.47 \\
Pre calving & 6.4 & 6.3 & 0.16 & 0.36 \\
Calving & 6.1 & 6.2 & 0.13 & 0.45 \\
AI & 5.5 & 5.6 & 0.14 & 0.41 \\
AI pregnancy determination & 5.4 & 5.3 & 0.15 & 0.77 \\
Weaning & 4.8 & 4.8 & 0.18 & 0.99 \\
\hline
\end{tabular}

${ }^{1} \mathrm{BW}=$ body weight; $\mathrm{AI}=$ artificial insemination; $\mathrm{BCS}=$ body condition score 
${ }^{2} \mathrm{CON}=$ cows were supplemented soybean hulls mixed with $155 \mathrm{~g} \mathrm{DM} / \mathrm{cow} / \mathrm{d}$ EnerGII (Virtus Nutrition LLC, Corcoran, CA) for $77 \pm 6$ days prepartum

${ }^{3}$ PUFA $=$ cows were supplemented soybean hulls mixed with $80 \mathrm{~g} \mathrm{DM} / \mathrm{cow} / \mathrm{d}$ Strata $+80 \mathrm{~g}$ DM/cow/d Prequel (Virtus Nutrition LLC, Corcoran, CA) for $77 \pm 6$ days prepartum

Table 6. Effects of late gestation supplementation of Ca salts of saturated/monounsaturated fatty acids (CON) or polyunsaturated fatty acids (PUFA) on milk production ${ }^{1}$ and cow reproductive performance

\begin{tabular}{lllll}
\hline Item & CON $^{2}$ & PUFA $^{3}$ & SEM & $P$-value \\
\hline Milk production (kg/d) & 8.6 & 9.4 & 0.75 & 0.33 \\
Composition & & & & \\
$\quad$ Fat, \% & 2.4 & 2.3 & 0.36 & 0.75 \\
$\quad$ Protein, \% & 3.1 & 3.0 & 0.10 & 0.38 \\
$\quad$ Lactose, \% & 4.8 & 4.8 & 0.05 & 0.23 \\
$\quad$ Other solids, \% & 6.1 & 6.0 & 0.06 & 0.35 \\
$\quad$ Total solids, \% & 11.7 & 11.4 & 0.36 & 0.48 \\
$\quad$ MUN, mg/dL & 14.0 & 14.5 & 0.89 & 0.59 \\
AI pregnancy, \% & 75 & 64 & - & 0.35 \\
Overall pregnancy, \% & 93 & 97 & 4.3 & 0.46 \\
\hline
\end{tabular}

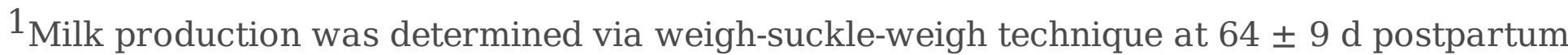
on a subset of 7-9 pairs/group; Milk composition conducted on a subset of cows (4 cows/group) at $64 \pm 9 \mathrm{~d}$ postpartum; $\mathrm{MUN}=$ milk urea nitrogen; $\mathrm{AI}=$ artificial insemination

${ }^{2} \mathrm{CON}=$ cows were supplemented soybean hulls mixed with $155 \mathrm{~g} \mathrm{DM} / \mathrm{cow} / \mathrm{d}$ EnerGII (Virtus Nutrition LLC, Corcoran, CA) for $77 \pm 6$ days prepartum ${ }^{3}$ PUFA $=$ cows were supplemented soybean hulls mixed with $80 \mathrm{~g} \mathrm{DM} / \mathrm{cow} / \mathrm{d}$ Strata $+80 \mathrm{~g}$ DM/cow/d Prequel (Virtus Nutrition LLC, Corcoran, CA) for $77 \pm 6$ days prepartum

Table 7. Effects of late gestation supplementation of Ca salts of saturated/monounsaturated fatty acids (CON) or polyunsaturated fatty acids (PUFA) on fatty acid profile of milk fat 


\begin{tabular}{|c|c|c|c|c|}
\hline Item & $\mathrm{CON}^{1}$ & $\mathrm{PUFA}^{2}$ & $\overline{\text { SEM }}$ & $P$-value \\
\hline \multicolumn{5}{|c|}{ Fatty acid, \% of total fatty acids } \\
\hline $\mathrm{C} 4: 0$ & 3.76 & 3.73 & 0.133 & 0.80 \\
\hline C6:0 & 1.64 & 1.60 & 0.064 & 0.52 \\
\hline C8:0 & 0.97 & 0.93 & 0.057 & 0.53 \\
\hline C10:0 & 2.06 & 1.97 & 0.170 & 0.64 \\
\hline C12:0 & 2.37 & 2.32 & 0.216 & 0.85 \\
\hline C14:0 & 8.05 & 7.74 & 0.446 & 0.51 \\
\hline C15:0 & 1.01 & 1.07 & 0.043 & 0.24 \\
\hline C16:0 $0^{3}$ & 22.7 & 21.6 & - & 0.19 \\
\hline C16:1c9 & 1.41 & 1.40 & 0.082 & 0.88 \\
\hline C17:0 & 0.65 & 0.66 & 0.025 & 0.52 \\
\hline C18:0 & 11.38 & 11.31 & 0.799 & 0.93 \\
\hline C18:1t4 & 0.04 & 0.04 & 0.003 & 0.62 \\
\hline C18:1t5 & 0.03 & 0.03 & 0.003 & 0.76 \\
\hline C18:1t6, 8 & 0.47 & 0.49 & 0.024 & 0.44 \\
\hline C18:1t9 & 0.36 & 0.37 & 0.015 & 0.47 \\
\hline C18:1t11 & 4.62 & 4.70 & 0.22 & 0.72 \\
\hline C18:1t12 & 0.39 & 0.41 & 0.020 & 0.58 \\
\hline C18:1c9 & 23.83 & 24.65 & 1.099 & 0.49 \\
\hline C18:1c11 & 0.42 & 0.40 & 0.027 & 0.58 \\
\hline C18:1c12 & 0.12 & 0.12 & 0.007 & 0.84 \\
\hline C18:1t16 & 0.32 & 0.32 & 0.012 & 0.59 \\
\hline C18:2t11, c15 & 0.11 & 0.09 & 0.018 & 0.52 \\
\hline C18:2n-6 & 2.58 & 2.72 & 0.14 & 0.37 \\
\hline C20:0 & 0.17 & 0.17 & 0.014 & 0.76 \\
\hline C20:1c11 & 0.05 & 0.05 & 0.003 & 0.66 \\
\hline C18:3n-3 & 0.50 & 0.52 & 0.030 & 0.36 \\
\hline C18:2c9, t11 & 2.22 & 2.28 & 0.14 & 0.66 \\
\hline C20:2n-6 & 0.02 & 0.02 & 0.002 & 0.48 \\
\hline C22:0 & 0.06 & 0.06 & 0.006 & 0.69 \\
\hline C20:3n-6 & 0.08 & 0.08 & 0.006 & 0.16 \\
\hline C20:4n-6 & 0.13 & 0.12 & 0.006 & 0.15 \\
\hline C20:5n-3 & 0.04 & 0.04 & 0.004 & 0.52 \\
\hline C22:5n-3 & 0.08 & 0.08 & 0.005 & 0.86 \\
\hline C22:6n-3 & 0.01 & 0.02 & 0.004 & 0.02 \\
\hline Total n-3 & 0.61 & 0.66 & 0.033 & 0.18 \\
\hline Total n-6 & 2.82 & 2.93 & 0.141 & 0.46 \\
\hline
\end{tabular}

${ }^{1} \mathrm{CON}=$ cows were supplemented soybean hulls mixed with $155 \mathrm{~g} \mathrm{DM} / \mathrm{cow} / \mathrm{d}$ EnerGII (Virtus Nutrition LLC, Corcoran, CA) for $77 \pm 6$ days prepartum

${ }^{2}$ PUFA = cows were supplemented soybean hulls mixed with $80 \mathrm{~g} \mathrm{DM} / \mathrm{cow} / \mathrm{d}$ Strata $+80 \mathrm{~g}$ DM/cow/d Prequel (Virtus Nutrition LLC, Corcoran, CA) for $77 \pm 6$ days prepartum

${ }^{3}$ Data were transformed for statistical analysis because of non-normal distribution; Means are presented after back-transformation

Table 8. Effects of late gestation supplementation of Ca salts of saturated/monounsaturated fatty acids (CON) or polyunsaturated fatty acids (PUFA) on calf performance 


\begin{tabular}{lcccc}
\hline Item $^{1}$ & CON $^{2}$ & PUFA $^{3}$ & SEM & $P$-value \\
\hline Gestation length, d & 275.3 & 276.2 & 1.26 & 0.46 \\
Birth BW, kg & 37.5 & 37.3 & 0.62 & 0.75 \\
Weaning BW, kg & 206 & 195 & 4.4 & 0.05 \\
Pre-weaning ADG, kg/d & 0.91 & 0.85 & 0.023 & 0.06 \\
Weaning age, d & 186 & 185 & 1.5 & 0.57 \\
\hline
\end{tabular}

${ }^{1} \mathrm{BW}=$ body weight; $\mathrm{ADG}=$ average daily gain

${ }^{2} \mathrm{CON}=$ cows were supplemented soybean hulls mixed with $155 \mathrm{~g} \mathrm{DM} / \mathrm{cow} / \mathrm{d}$ EnerGII (Virtus Nutrition LLC, Corcoran, CA) for $77 \pm 6$ days prepartum

${ }^{3}$ PUFA = cows were supplemented soybean hulls mixed with $80 \mathrm{~g} \mathrm{DM} / \mathrm{cow} / \mathrm{d}$ Strata $+80 \mathrm{~g}$ DM/cow/d Prequel (Virtus Nutrition LLC, Corcoran, CA) for $77 \pm 6$ days prepartum

Table 9. Relative expression of genes regulating myogenesis and adipogenesis in Longissimus muscle of the steers born from dams supplemented with Ca salts of saturated/monounsaturated fatty acids $(\mathrm{CON})$ or polyunsaturated fatty acids (PUFA) during late gestation ${ }^{1}$

\begin{tabular}{lccccccc}
\hline Gene $^{5}$ & \multicolumn{2}{c}{ Birth } & \multicolumn{2}{c}{ Weaning } & \multicolumn{3}{c}{$P$-value } \\
\cline { 2 - 8 } & CON $^{2}$ & PUFA $^{3}$ & CON & PUFA & Trt & time & Trt $\times$ time \\
\hline MYH1 & 0.854 & 0.897 & 1.324 & 1.212 & 0.85 & 0.00 & 0.50 \\
MYH2 & 1.014 & 0.883 & 1.367 & 1.159 & 0.18 & 0.01 & 0.90 \\
MYH7 & $1.032^{\mathrm{b}}$ & $0.923^{\mathrm{c}}$ & $1.136^{\mathrm{a}}$ & $1.173^{\mathrm{a}}$ & 0.18 & $<0.01$ & 0.02 \\
PAX7 & 1.134 & 1.067 & 0.971 & 0.979 & 0.34 & $<0.01$ & 0.18 \\
MYF5 & 1.418 & 0.987 & 0.915 & 0.894 & 0.08 & 0.01 & 0.07 \\
MYF6 & 0.887 & 0.627 & 1.694 & 1.544 & 0.18 & $<0.01$ & 0.23 \\
MYOD1 & 0.979 & 0.884 & 1.386 & 1.174 & 0.34 & 0.02 & 0.80 \\
MYOG & 1.053 & 0.830 & 1.280 & 1.042 & 0.08 & 0.05 & 0.88 \\
MEF2C & 1.504 & 1.323 & 0.976 & 0.969 & 0.56 & 0.00 & 0.50 \\
C/EBPa & 0.505 & 0.531 & 1.905 & 2.102 & 0.59 & $<0.01$ & 0.86 \\
C/EBPB & 0.186 & $0.163^{\mathrm{C}}$ & $0.422^{\mathrm{b}}$ & $0.566^{\mathrm{a}}$ & 0.46 & $<0.01$ & 0.04 \\
ZFP423 & 0.836 & 0.735 & 1.764 & 1.844 & 0.69 & $<0.01$ & 0.26 \\
FABP4 & 0.154 & 0.271 & 0.738 & 0.481 & 0.88 & 0.02 & 0.25 \\
PPARG & 0.316 & 0.298 & 0.727 & 0.679 & 0.63 & $<0.01$ & 0.98 \\
GPAT1 & 1.245 & 1.147 & 1.225 & 1.376 & 0.81 & 0.23 & 0.16 \\
PPARGC1A & 0.609 & 0.472 & 0.911 & 0.995 & 0.77 & 0.01 & 0.37 \\
\hline
\end{tabular}

$1_{\text {Means are back-transformed if transformation was conducted }}$

${ }^{2} \mathrm{CON}=$ cows were supplemented soybean hulls mixed with $155 \mathrm{~g} \mathrm{DM} / \mathrm{cow} / \mathrm{d}$ EnerGII (Virtus Nutrition LLC, Corcoran, CA) for $77 \pm 6$ days prepartum

${ }^{3}$ PUFA $=$ cows were supplemented soybean hulls mixed with $80 \mathrm{~g} \mathrm{DM} / \mathrm{cow} / \mathrm{d}$ Strata $+80 \mathrm{~g}$ DM/cow/d Prequel (Virtus Nutrition LLC, Corcoran, CA) for $77 \pm 6$ days prepartum

${ }^{4}$ Trt $=$ treatment effect; Trt $\times$ Time $=$ interaction between treatment and time

${ }^{5}$ MYH1 Myosin heavy chain 1, MYH2 Myosin heavy chain 2, MYH7 Myosin heavy chain 7, PAX7 Paired box protein 7, MYF5 Myogenic factor 5, MYF6 Myogenic factor 6, MYOD1 Myogenic differentiation 1, MYOG Myogenin, MEF2C Myocyte enhancer factor 2C, 
$C / E B P \alpha$ CCAAT enhancer binding protein alpha, $C / E B P \beta$ CCAAT enhancer binding protein beta, ZFP423 Zinc finger protein 423, FABP4 Fatty acid binding protein 4, PPARG Peroxisome proliferator activated receptor gamma, GPAT1 Glycerol-3-phosphate acyltransferase 1, PPARGC1A PPARG coactivator 1 alpha

Table 10. Relative expression of genes regulating adipogenesis in subcutaneous adipose tissue of the steers born from dams supplemented with Ca salts of saturated/monounsaturated fatty acids (CON) or polyunsaturated fatty acids (PUFA) during late gestation ${ }^{1}$

\begin{tabular}{lccccccc}
\hline Gene $^{5}$ & \multicolumn{2}{c}{ Birth } & \multicolumn{2}{c}{ Weaning } & \multicolumn{2}{c}{$P$-value } \\
\cline { 2 - 8 } & CON $^{3}$ & PUFA $^{2}$ & CON & PUFA & Trt & time & Trt $\times$ time \\
\hline$C / E B P \alpha$ & 1.094 & 0.903 & 0.830 & 0.727 & 0.22 & 0.02 & 0.62 \\
$C / E B P \beta$ & 0.319 & 0.266 & 0.241 & 0.267 & 0.68 & 0.09 & 0.08 \\
$Z F P 423$ & 0.978 & 0.812 & 1.396 & 1.149 & 0.02 & $<0.01$ & 0.56 \\
$F A B P 4$ & 0.922 & 0.992 & 1.095 & 1.071 & 0.88 & 0.17 & 0.61 \\
$P P A R G$ & 1.044 & 0.956 & 0.793 & 0.868 & 0.96 & 0.07 & 0.37 \\
$P P A R G C 1 A$ & 0.572 & 0.435 & 0.102 & 0.136 & 0.99 & $<0.01$ & 0.44 \\
$S C D$ & 0.771 & 1.096 & 0.238 & 0.131 & 0.70 & $<0.01$ & 0.08 \\
$F A S N$ & 0.897 & 0.964 & 0.202 & 0.131 & 0.57 & $<0.01$ & 0.33 \\
$S R E B P 1$ & 1.065 & 0.986 & 0.764 & 0.786 & 0.84 & $<0.01$ & 0.54 \\
$A C A C A$ & 0.946 & 1.151 & 0.182 & 0.144 & 0.94 & $<0.01$ & 0.37 \\
$A D F P$ & 0.943 & 0.735 & 0.720 & 0.808 & 0.69 & 0.57 & 0.25 \\
\hline
\end{tabular}

${ }^{1}$ Means are back-transformed if transformation was conducted

${ }^{2} \mathrm{CON}=$ cows were supplemented soybean hulls mixed with $155 \mathrm{~g} \mathrm{DM} / \mathrm{cow} / \mathrm{d}$ EnerGII (Virtus Nutrition LLC, Corcoran, CA) for $77 \pm 6$ days prepartum

${ }^{3}$ PUFA $=$ cows were supplemented soybean hulls mixed with $80 \mathrm{~g} \mathrm{DM} / \mathrm{cow} / \mathrm{d}$ Strata $+80 \mathrm{~g}$ $\mathrm{DM} / \mathrm{cow} / \mathrm{d}$ Prequel (Virtus Nutrition LLC, Corcoran, CA) for $77 \pm 6$ days prepartum ${ }^{4}$ Trt $=$ treatment effect; Trt $\times$ Time $=$ interaction between treatment and time

${ }^{5} S C D$ Stearoyl-CoA desaturase, FASN Fatty acid synthase, SREBP1 Sterol regulatory element binding transcription factor 1, ACACA Acetyl-CoA carboxylase alpha, ADFP Adipose differentiation-related protein

\section{Supplementary Files}

This is a list of supplementary files associated with this preprint. Click to download.

- JASBAdditionalfile.docx 